\title{
The Role of International Criminal Law in Environmental Protection
}

\begin{abstract}
They draw too heavily, too quickly, on already overdrawn environmental resource accounts to be affordable far into the future without bankrupting those accounts. They may show profit on the balance sheets of our generation, but our children will inherit the losses. We borrow environmental capital from future generations with no intention or prospect of repaying. They may damn us for our spendthrift ways, but they can never collect on our debt to them. We act as we do because we can get away with it: future generations do not vote; they have no political or financial power; they cannot challenge our decisions.[i]
\end{abstract}

\section{Introduction}

Industrialisation of the world has transformed the traditional understanding of the relationship between human beings and nature. The conventional worship, or at least, respect for the sanctity of the Earth[ii] has been replaced by a notion that nature's sole function is to provide human beings with unlimited resources for survival and economic expansion. Every modern global economic system is based on the concept of growth without allowing for the simple fact that the riches of the planet are limited.[iii] Thus every industrialised state has an inexhaustible demand for natural resources which causes unsustainable pollution of air, water and soil; deforestation, desertification, [iv] land degradation, depletion of non-renewable resources, loss of biodiversity as well as long-term damage to ecosystems. It will not be terrorism, religious wars or a financial crisis that will be the major concern of humanity in the $21^{\text {st }}$ century but finding ways for a sustainable cohabitation with the ecosystem.

In the late 1960s and early 1970s states began to acknowledge the urgency of the problem[v] but it was soon realised that at the rate of today's destruction we have long passed the stage where the environment was only a national problem.[vi] Problems such as air and water pollution or desertification do not stop at state borders and but often affect a whole region. Many of Africa's most serious environmental problems have an international angle; as McLaughlin puts it, 'internalisation of environmental destruction'.[vii] At the end of the first decade of the $21^{\text {st }}$ century one can find a plethora of legal instruments on environmental protection. However, as will be shown, neither national nor international environmental law offers effective protection against the very worst acts of environmental destruction in Africa. Gross corporate environmental violations in particular appear largely unsanctioned.

This chapter argues that although it is acknowledged that national, international regulatory and self-regulation instruments are to some extent effective in protecting the environment,[viii] for the most extreme violations of environmental law, criminal condemnation and punishment is needed. Thus international criminal law should be extended to cover serious environmental offences, especially when committed by corporations. It will be proposed that the International Criminal Court should extend its jurisdiction to legal persons and introduce the new international crime of 'grave crimes against the environment'. The remainder of this chapter will analyse existing national and international legal responses to gross environmental damage and show the necessity and feasibility of the proposed new crime. 


\section{Peacetime Environmental Damage and International Environmental Law[ix]}

The protection of the environment as a main focus appeared relatively late in international law. Once the problem had gained international attention however, an ever-growing body of international environmental treaties and conventions emerged. [x] In the first half of the century a number of international instruments were adopted dealing with protection of the wildlife such as fur seals,[xi] whales, [xii] fish, [xiii] polar bears, [xiv] and birds.[xv] Other conventions were more general, such as the Convention Relative to the Preservation of Fauna and Flora in their Natural State in Africa[xvi] and the Convention on International Trade in Endangered Species of Wild Fauna and Flora.[xvii] Instruments concerned with pollution include the 1954 International Convention for the Prevention of Pollution of the Sea by Oil,[xviii] the 1973 International Convention for Prevention of Pollution from Ships,[xix] the 1979 Geneva Convention on LongRange Transboundary Air Pollution[xx].

A major stepping stone in rectifying this problem was the Stockholm Conference in 1972, which aimed to find a global approach to environmental problems. The two major outcomes was the establishment of the United Nations Environment Program (UNEP)[xxi] and the Stockholm Declaration on the Human Environment (Stockholm Declaration).[xxii] The Stockholm Declaration set out 26 non-binding principles of environmental protection including issues such as sustainability, conservation of wildlife and habitat, toxic substances, pollution of the seas, population growth, nuclear weapons and the ecological balance of the biosphere. Important areas that were not covered include carbon dioxide production, global warming, biological diversity, chemical and biological weapons and ozone depletion.[xxiii] The latter was encompassed by the Vienna Convention for the Protection of the Ozone Layer. This and its progeny amount to perhaps the most substantial achievement of all.[xxiv]

In spite of the growing body of international environmental law, the existing methods for creating international environmental law are still "slow, cumbersome, expensive, uncoordinated and uncertain".[xxv] Different agencies such as the World Meteorological Organization, the International Maritime Organization, the World Health Organisation, the Food and Agriculture Organization, the United Nations Development Programme as well as the United Nations Educational, Scientific and Cultural Organization deal with questions regarding the environment at the United Nations level. Although the general assembly created UNEP in order to coordinate this work, it is has to be noted that "[n]early twenty years after the Stockholm Declaration, we still lack the institutional and legal mechanisms to deal effectively with transboundary and biospheric environmental degradation.' [xxvi] Most importantly, each treaty has to be agreed upon in long negotiation procedures without any consistent standard of enforcement, monitoring or interpretation of standards. Palmer observes: “...every time a new instrument is negotiated, fresh machinery has to be devised", which means "the grave risk that on each occasion the wheel must be reinvented." [xxvii] Still, the continuous expansion of international environmental law has raised global awareness that the unrestrained use of nature is no longer tenable.[xxviii] Unfortunately, this growing interest in the environment "has paralleled an ever accelerating pace of destruction of the planet's ecosystem"[xxix]. The fear that environmentally sound production techniques are too expensive for the poorest countries and thus any binding rules would hinder economic development, preventing international environmental law from developing a strong enforcement regime. 
In sum, the methods and techniques now available to fashion new instruments of international law to cope with global environmental problems cannot meet that challenge. The emerging issues are so big and so all-embracing that current ways of doing things will not solve these problems.[xxx]

Moreover the proliferation of international instruments, impressive as it is, suffers from a scarcity of ratifications and enforcement at national levels.[xxxi] Levy et al even claim that there is not much indication that environmental rules are enforced by international organisations who engage in only symbolic responses.[xxxii] Without denying its important role, international environmental law at the moment is unable to prevent the most serious environmental crimes.

\section{Wartime Environmental Damage and International Environmental Law}

\section{Environmental Damage in Wartime}

When discussing the effectiveness of international environmental law in Africa it is often overlooked how much environmental harm is caused in the context of armed conflict for the following reasons:

i) the environment might be targeted directly as part of the war strategy,

ii) environmental damage is a side-effect of armed violence and

iii) the plundering of natural resources is used to finance the conflict.

As part of battlefield strategy the environment has been targeted throughout history in order to deprive the enemy of food, water and cover. A modern example is the use of chemical defoliants in Vietnam and throughout history one can find cases of scorched earth practice. Attacks on the environment can also be used as a tactic against the civilian population (especially if it is indigenous) by cutting the people off from water, food, shelter and fuel supplies. Additionally, the plundering of resources might also be employed as a form of reprisal.[xxxiii]

Secondly, environmental destruction is often an inevitable result of war.[xxxiv] Such unintended consequences of armed conflict include environmental harm following the use of indiscriminate weapons and tactics such as attacks on civilian chemical and petroleum facilities.[xxxv] Furthermore, movement of troops, especially heavy vehicles and the digging of trenches[xxxvi] often damage the natural environment, particularly when the soldiers are poaching for food or constructing field camps.[xxxvii] Another problem is the impacts of forced movement of populations. Refugees and displaced persons have an impact on natural resources, which are needed to provide extra shelter, food, cooking fuel and water. Bruch warns that in addition "internal armed conflicts often produce armed and lawless societies that can severely impact the environment."'[xxxviii]

The third group of environmental damage in the context of armed conflict is mainly found in civil war situations where at least one of the parties needs to look for extra ways to generate revenue for feeding and arming their combatants. For example, significant environmental damage was caused during many of the civil wars financed with proceeds from diamond mining. The consequences of relying on mining to finance civil conflicts are aptly captured in this extract; 
For the last two decades diamond mining activities have focused on quick revenues to fuel the civil war. This has resulted in the use of outdated and environmentally damaging mining procedures and equipment.

Pipe mining is a type of open-pit mining that removes large quantities of "overburden" (rocks and dirt) in order to access the diamonds. Large areas of land and surrounding ecosystems are disturbed and damaged. Generally, the overburden is not properly disposed of, which causes further damage. In addition, acid mine drainage can occur. Not surprisingly, in Angola, Congo and Sierra Leone, there is virtually no oversight of mining operations. In these regions, in addition to the human costs associated with "conflict diamonds," the environmental toll of diamond mining operations can be steep pits are left open and loose fill is left unmanaged to run off into rivers and streams, often with catastrophic effects.

An additional result of diamond mining is the diversion of rivers to allow for the mining of alluvial diamond deposits. When the mine is depleted, the rivers are not redirected to their original courses, which in turn results in the pollution of waters and destruction of surrounding flora and fauna. The mining activities also degrade the surrounding land by increasing atmospheric air pollution, contaminating surface and ground water and increasing soil erosion and leaching. The pollution is, in the most extreme cases, leading to desertification and permanently changing land use from agriculture to waste, rendering it useless to traditional inhabitants when the diamonds have all been mined. In the short run the inhabitants of the region are suffering from sickness and disease related to contaminated drinking water supplies. Such diseases include dysentery, malaria, schistosamiases and Biomphalaria pfeiffer.[xxxix]

The trade with multinational corporations in diamonds allowed the rebels to purchase weapons light enough for children as young as 8 to carry them.[xl] The revenue generated from the illegal diamond trade is also used to fund the drugs, which are needed to make children more aggressive and able to commit these atrocities as well as using their addiction to control them.[xli], [xlii] Other examples of conflict commodities are oil in Sudan, gold and coltan[xliii] in the Democratic Republic of Congo.[xliv] In addition, wildlife is endangered by soldiers hunting for food and poaching for husk, killing elephants, rhinos and buffalos.[xlv] Furthermore, if one side has identified an available natural source, this then invites attacks on those resources from opposing forces, further damaging the environment.[xlvi]

Multinational corporations are involved in these crimes when they take advantage of a close relationship with an oppressive government or regime to exploit natural resources in the conflict zones[xlvii] and trade in conflict commodities.[xlviii] A corporation might facilitate the ongoing violence by supplying the oppressors with the revenue needed to fund the armed conflict and access global arms markets.[xlix] For example, the Glasgow-based Weir group which manufactures oil pumps was accused of having a close relationship with the Khartoum government, which it supported by financing its conflicts in Sudan.[1] Regrettably it has to be recognised that the "influence of some multinational corporations on war situations and on parties to conflict is growing steadily"[li] and that they increasingly motivate and fuel the conflict.[lii]

\section{International Environmental Law in Wartime}


The long-term effects of environmental damage caused as part of belligerent operations "may have serious consequences for human health, economic stability, and future ecosystem balance."[liii] Compared to international environmental law in peacetime, the development of international law regarding environmental protection during wartime is still lagging behind.[liv] Nevertheless there are a number of relevant legal instruments that are applicable under certain circumstances. These are discussed in the next section.

\section{Hague Conventions}

The 1907 Hague Conventions codify international law of armed conflict and set out the main principles which govern international humanitarian law - necessity, proportionality, discrimination, and humanity - . [lv] Not surprisingly these old instruments do not explicitly mention environmental protection, however, some provisions can be applied to environmental issues. According to Article 55 of Hague Convention II,[lvi] the occupying power may not permanently alter or destroy enemy territory and irresponsibly use the natural resources found therein. Furthermore, parts of the environment and natural resources can be interpreted as property of the enemy and therefore fall under the protection of Article 23(g) of Hague Convention II, which prohibits the destruction and seizure of enemy property. However, it is unclear the extent to which the term 'property' encompasses such natural assets as water, air, forests, and wild animals, which are not under specific ownership.[1vii] Moreover, even allowing for a wide interpretation of the term property, any environmental protection by The Hague Conventions is limited by the defence of military necessity.[1viii] The parameters of this principle are very vague and extremely difficult to define. DuBarry Huston argues that "[s]ituations are rare, if ever, where necessity does not excuse this conduct."[lix] Yet, there are examples where aggressors intentionally caused devastating damage to the environment without being able to show any significant military advantage. For example, the torching of the oil wells in Kuwait and the release of oil into the Gulf did not give Iraq any noteworthy military advantage, while at the same time causing major environmental damage.[1x]

Violators of the Hague Conventions are liable to pay compensation under article 3 of 1907 Hague Convention Number IV, but the Conventions do not provide any enforcement mechanisms, neither do they proscribe any criminal responsibility. Thus, the limited protection of the environment in the Hague Conventions is of very little effectiveness.

\section{Geneva Conventions}

Like the Hague conventions, the Fourth Geneva Convention of 1949[1xi] also provides for the protection of property.[1xii] For example, article 33 outlaws pillaging, article 53 Geneva IV prohibits the destruction by the occupying power of property belonging to the State or to other public authorities and article 51 outlaws extensive destruction and appropriation of property.[1xiii] Article 3 of the Four Geneva Conventions (Common article 3), which is the basis for humanitarian protection in non-international armed conflicts, lacks any mention of environmental damage, however, the term "violence to life and person" in article 3(1)(a) offers indirect protection as it prohibits the use of poisonous gas or scorched earth practice.[1xiv]

Article 147 of Geneva IV describes the "extensive destruction and appropriation of property, not justified by military necessity and carried out unlawfully and wantonly" as a "grave breach" of the Convention. Grave breaches of the Convention trigger civil as well as criminal liability.[1xv] 
Therefore, unlike the Hague Conventions, the Geneva Conventions offer a route to prosecute individuals for serious damage to the environment. However, as in the Hague Conventions, the four Geneva Conventions provide the defence of military necessity for destructive conduct.[1xvi]

\section{Additional Protocols and ENMOD}

The environmental damage caused during the Vietnam War when the United States military used defoliant herbicides[lxvii], incendiary weapons, removal of topsoil and rainmaking techniques,[1xviii] triggered a widespread international objection, which resulted in three conventions: Additional Protocol I to the Geneva Conventions,[lxix] which governs international armed conflicts (Additional Protocol I), Additional Protocol II to the Geneva Conventions,[1xx] which governs non-international conflicts (Additional Protocol II) and the Convention on the Prohibition of Military or Any Other Hostile Use of Environmental Modification Techniques (ENMOD).[1xxi]

Additional Protocol I offers a more direct protection to that of The Hague Convention or the Geneva Conventions as it specifically mentions the environment as a subject of its protection. Articles 35(3)[1xxii] and 55(1)[1xxiii] of Protocol I explicitly outlaws "widespread, long-term and severe damage to the natural environment". According to the International Committee of the Red Cross Commentary on Protocol I, the term 'environment' should be defined broader than "property" under the 1907 Hague Convention IV or Geneva Convention IV and "understood in the widest sense to cover the biological environment in which a population is living."[lxxiv] Furthermore, the defence of military necessity is restricted in Additional Protocol I. Articles 35(3) and 55 outlaw severe damage to the environment even when the military objective outweighs the damage to the environment. Moreover, both articles introduce the objective standard of reasonable foreseeability.[1xxv] This means that it is sufficient to prove the possibility of foresight rather than direct intention. Unfortunately, each term is quite vague and allows a very restricted interpretation.[1xxvi] The effectiveness of Additional Protocol I is further limited due to the fact that it requires a very high threshold of damage. The environmental harm has to meet all three conditions of "severe", "long-term", and "widespread".

The great advantage of Protocol I compared with the Hague and Geneva Conventions is that it does not provide for the defence of military necessity. However, this concession comes at a high price since the absence of this defence deterred a number of major powers from ratification.[1xxvii] Additional Protocol I therefore remains a weak legal instrument with its provisions not becoming customary law.

Additional Protocol II elaborates on the principles of Common Article 3 that governs internal armed conflicts. The diplomatic conference that drafted both Additional Protocols at the same time rejected a proposal to include environmental provisions in Additional Protocol II, which would mirror the protection of Articles 35(3) and 55 of the Additional Protocol I.[1xxviii] Thus Additional Protocol II does not explicitly mention the environment. However, Articles 14 and 15 Additional Protocol II might offer implicit protection for the environment under the following circumstances. Article 14 of Additional Protocol II outlaws starvation, which would include scorched earth practices or the use of poisonous gas if used targeting crops or livestock. Article 15 Additional Protocol II prohibits attacks on drinking water installations and irrigation works. In 
addition, scorched earth practices, attacks on nuclear power plants and chemical facilities or attacks on protected areas fall under the prohibition of article 17 of Additional Protocol II if they form part of forced movement of civilians. However, like the Hague Conventions, Additional Protocol II does not offer implementation provisions and lacks the grave breach provisions of Geneva Conventions and Protocol I.

Thus, Additional Protocol II offers less environmental protection and less enforceability than Additional Protocol I. This means that in non-international armed conflicts, international humanitarian law offers a very limited environmental protection. However, national and international criminal courts and tribunals can choose to include violations of Additional Protocol II in their subject jurisdiction. For example, the Statute for the International Criminal Tribunal for Rwanda[lxxix] included provisions allowing for people to be held criminally liable for serious violations of Common Article 3 of the Geneva Conventions and Additional Protocol II.[1xxx]

The Convention on the Prohibition of Military or Any Other Hostile Use of Environmental Modification Techniques is the first international treaty that specifically governs environmental impacts of armed conflict as a distinct issue and is thus celebrated as a milestone in the development of environmental law of war.[1xxxi]This Convention deals with techniques that manipulate the climate, earthquakes, the ozone layer, tidal waves and ocean currents. Article 2 ENMOD defines environmental modification techniques as "any technique for changing - through the deliberate manipulation of natural processes - the dynamics, composition or structure of the earth, including its biota, lithosphere, hydrosphere and atmosphere, or of outer space".[1xxxii] Unlike Common Article 3 and Additional Protocol II, ENMOD is not limited to international conflicts and like Additional Protocol I, ENMOD does not allow the defence of military necessity. Furthermore, it has a lower threshold than Additional Protocol I as it requires the harm to meet only one of the three conditions of 'widespread, long-lasting, and severe'.[1xxxiii] The major weakness of ENMOD is that its scope is very limited and conventional combat techniques are not included.[lxxxiv] Thus most of today's environmental damage caused in armed conflict is not covered.

The importance of ENMOD and the relevant environment provisions of Additional Protocol I is that environmental damage is prohibited on its own even if not direct suffering of human beings can be shown.[lxxxv] However, none of these international treaties offer comprehensive and enforceable protection against gross environmental damage in the context of armed conflict.

\section{Rules against specific weapons}

Further environmental protection during armed conflict is offered by the international legal instruments that prohibit the use of certain weapons. Landmines, for example, not only have a shattering impact on human life, limbs and economic development but also on the environment, especially the wildlife. Countries such as Angola and Mozambique have suffered from the longterm consequences of landmines long after the end of the conflicts.[1xxxvi] The same is true for cluster bombs, whose highly explosive bullets remain a danger for wildlife for a very long time. Likewise, depleted uranium munitions are highly harmful for the environment because of their radioactive and toxic dust as well as the aerosol residue. Therefore, instruments such as the Convention on the Prohibition of the Use, Stockpiling, Production and Transfer of AntiPersonnel Mines and their Destruction,[lxxxvii] the Amended Protocol II on Anti-Personnel LandMines to the 1980 United Nations Convention on Certain Conventional Weapons,[lxxxviii] the Protocol for the Prohibition of the Use in War of Asphyxiating, Poisonous or Other Gases, and of 
Bacteriological Methods of Warfare[lxxxix] indirectly protect the environment.

\section{Rules Protecting Cultural Property}

Very often parts of the environment are so intrinsically interwoven with a society's culture that it can fall under the protection of cultural property. In this case an indirect avenue for prosecution for environmental injury during armed conflict could be a convention or international treaty protecting cultural property. For example the Convention for the Protection of Cultural Property in the Event of Armed Conflict[xc] protects "monuments of architecture, art or history, whether religious or secular; archaeological sites; groups of buildings which, as a whole, are of historical or artistic interest; works of art; [...] objects of artistic, historical or archaeological interest; as well as scientific collections and important collections of books or archives or of reproductions of the property defined above"[xci]. Thus attacks of natural areas, enclosing for example religious shrines, are banned.[xcii] The Convention prohibits targeting, pillaging or otherwise damaging these protected sites unless "where military necessity imperatively requires such a waiver."'[xciii] However, the Second Protocol to the Cultural Property Convention[xciv] provides clear standards for the defence of military necessity $[\mathrm{xcv}]$ and mitigation measures that belligerents would then need to undertake.[xcvi] This Protocol also extends its protection to noninternational armed conflicts.[xcvii] It has been argued that the convention and its protocols could be used as models for a treaty specifically tailored to the protection of the environment in internal armed conflicts, including provisions for criminal prosecutions.[xcviii]

\section{Rome Statute}

Compared to other conflicts, the environmental damage caused during the armed conflicts in Former Yugoslavia and Rwanda was not very grave.[xcix] Thus it does not come as a surprise that the Statutes of neither the International Criminal Tribunal for Former Yugoslavia (ICTY)[c] nor for the International Criminal Tribunal for Rwanda (ICTR)[ci] mention the environment explicitly. As in the previously discussed international instruments, the environment is to some extent indirectly protected through the prohibition of wanton destruction[cii] and pillaging.[ciii]

The first international criminal court to have direct jurisdiction over environmental damage is the International Criminal Court. Article 8(2)(b)(iv) of the Rome Statute of the International Court (Rome Statute)[civ] forbids

[i]ntentionally launching an attack in the knowledge that such attack will cause [...] widespread, long-term and severe damage to the natural environment which would be clearly excessive in relation to the concrete and direct overall military advantage anticipated.

Similar to the Additional Protocol I, the damage to the environment needs to meet the high threshold of all three criteria of widespread, long-term and severe damage. Furthermore, the Rome Statute requires an intention and unlike ENMOD and Additional Protocol I, recklessness is not sufficient. In addition, it allows the defence that the damage was not 'clearly excessive' on balance with the military advantage. While both terms 'clearly' and 'excessive' are open to interpretation, the criterion of military advantage is a subjective standard as it only needs to be anticipated rather than objectively determined. Consequently, it would be very easy to argue for the defendant who had launched an environmentally devastating attack that they thought they would achieve a military advantage that was worth the damage and thus not clearly excessive. A 
further limit to the environmental protection of this provision is that it only applied to international armed conflicts whereas many of the current conflicts are of a non-international nature. The proposal to define war crimes for environmental harm in the context of internal armed conflicts was regrettably rejected.[cv]

Like Additional Protocol II, the Rome Statute provides for a number of war crimes which can apply indirectly to the causation of environmental damage. Thus attacks on religious institutions, attacks on natural areas containing historical and cultural monuments and scorched earth tactics are forbidden. The Nuremberg trials which saw two trials for scorched earth practice was however the last time a prosecution focussed on environmental damage in the context of armed conflict. The displacement of civilian population is prohibited by article 8(2)(e)(viii) of the Rome Statute "unless the security of the civilians involved or imperative military reasons so demand". Article 8(2)(e)(xii) Rome Statute bans "[d]estroying or seizing the property of an adversary unless such destruction or seizure be imperatively demanded by the necessities of the conflict". Severe damage of the environment can even constitute genocide under Article 6(c) Rome Statute when it causes "deliberately inflicting on the group conditions of life calculated to bring about its physical destruction in whole or in part," for example widespread intentional soil salinisation. This is especially true for areas where indigenous people live who depend on natural resources for survival.[cvi] Environmental damage can also constitute a crime against humanity according to Article 7 Rome Statute if a widespread or systematic attack against the civilian population includes pollution of drinking water, destruction of food sources or other natural resources.

\section{Other Avenues}

Bruch argues that even those international environmental treaties that are designed for peacetime can be used in cases of armed conflict.[cvii] For example, the Convention on International Trade in Endangered Species[cviii] could be applied when the sale of ivory is used to finance military operations, and the Basel Convention[cix] could encompass the movement of military materiel. However, it is still unclear to what extent peacetime environmental law is applicable to the situation of armed conflict. Nevertheless, international environmental law should be used as a basis for interpretation of Common Article 3, Protocol II, ENMOD and other relevant instruments in cases of natural damage. [cx]

\section{Conclusions}

From the analysis of international legal instruments that deal with environmental protection during armed conflict, a disappointing picture emerges. The rules of armed conflict only rarely deal with the environment directly.[cxi] The inclusion of a vague defence of military defence, high mens rea and actus reus thresholds and the restriction to international conflicts, while most contemporary conflicts are internal, leave the impunity gap for the worst environmental offenders wide open. In addition none of these instruments deal with corporate responsibility.[cxii] What was declared for human rights[cxiii] is equally true for environmental crimes:

Though corporations are capable of interfering with the enjoyment of a broad range of human rights, international law has failed both to articulate the human rights obligations of corporations and to provide mechanisms for regulating corporate conduct in the field of 
human rights.[cxiv]

\section{Corporate Responsibility in International Law}

When considering the responsibility of corporations for environmental crimes, two characteristics of international environmental law are relevant. First of all, most legal instruments in international environmental law provide guidance rather than enforcement. It mainly focuses on prevention of, rather than reaction to, environmental damage. Secondly, it is based on the notion of the responsibility lying with the state, rather than with the direct actors who cause the harm. As indicated above, these features of international environmental law renders it largely ineffective. In what follows next, we will evaluate the international law instruments that directly regulate corporate conduct and are seen to remedy some of the weaknesses of 'traditional' international environmental law.

As early as 1976 the Organisation for Economic Co-operation and Development (OECD) adopted Guidelines for Multinational Enterprise (Guidelines), [cxv] which consist of recommendations for enterprises relating to human rights, employment, environments and consumer interest. The Guidelines were quite innovative because they provide for National Contact Points (NCP), which are national offices for the promotion and implementation of the Guidelines. If a NCP receives a grievance about a corporation that has allegedly breached the Guidelines, they can offer mediation or conciliation between the complainant and the corporation in question.[cxvi] However, there are no sanctions against multinational corporations for not adhering to the Guidelines. In respect to serious damage to the environment, mediation and conciliation do not seem to reflect sufficiently the gravity of the harm done to nature and people. Moreover, the NCP are free to decide that the complaint requires no further action. Unsurprisingly, only 24 cases have been heard since 1976, two of which occurred after 1990.

The International Labour Organization (ILO) has attempted to regulate corporate conduct too. One of the major ILO instruments, which affect the work of multinational corporations, is the Tripartite Declaration of Principles Concerning Multinational Enterprises and Social Policy (Tripartite Declaration).[cxvii] This declaration regulates the conduct of multinational corporations and defines the terms of relations between corporations and host countries. Like the OECD Guidelines, the Tripartite Declaration is not binding and does not provide for sanctions. Rather than policing multinational corporations, the main purpose is to use diplomacy, dialogue and moral persuasion to encourage compliance by the member states.

Another significant international instrument is the United Nations Global Compact Initiative (Global Impact), which was developed in 1999 by the former United Nations Secretary General Kofi Annan. This document promotes a number of shared values and corporate citizenship[cxviii]by formulating ten[cxix] basic human rights principles which should be adhered to by business corporations.[cxx] Principles 7-9 declare that businesses should support a precautionary approach to environmental challenges, undertake initiatives to promote greater environmental responsibility and encourage the development and diffusion of environmentally friendly technologies. It, however, relies on the co-operation of multinational corporations which means it lacks independent monitoring and policing mechanisms. Moreover, it does not provide for any form of sanction or compensation for the victims. 
In 2003 the United Nations Sub-Commission for the Promotion and Protection of Human Rights formulated the Norms on the Responsibilities of Transnational Corporations and Other Business Enterprises with Regard to Human Rights.[cxxi] The Norms confirm that multinational corporations are not only subject to human rights but also have human duties and responsibilities.[cxxii] Para 4 of the preamble emphasises the co-responsibility of governments and multinational corporation:

Realizing that transnational corporations and other business enterprises, their officers and persons working for them are also obligated to respect generally recognized responsibilities and norms contained in United Nations treaties and other international instruments such as [...] the Convention on Biological Diversity; the International Convention on Civil Liability for Oil Pollution Damage; the Convention on Civil Liability for Damage Resulting from Activities Dangerous to the Environment; the Declaration on the Right to Development; the Rio Declaration on the Environment and Development; the Plan of Implementation of the World Summit on Sustainable Development; the United Nations Millennium Declaration[...][cxxiii]

What is more, the Norms directly address corporations' responsibility for environmental protection. Section 14 provides that

[t]ransnational corporations and other business enterprises shall carry out their activities in accordance with national laws, regulations, administrative practices and policies relating to the preservation of the environment of the countries in which they operate, as well as in accordance with relevant international agreements, principles, objectives, responsibilities and standards with regard to the environment as well as human rights, public health and safety, bioethics and the precautionary principle, and shall generally conduct their activities in a manner contributing to the wider goal of sustainable development.

As one can see, the Norms do not create new responsibilities or extend existing protection but rather compile human rights norms that already exist in other international instruments. However, compared with other international instruments the Norms signify an improvement, as sections 1519 provide for a structured implementation mechanism. Corporations are required to incorporate them in their contracts with all business partners and "adopt, disseminate and implement internal rules of operation in compliance with the norms." [cxxiv] Further, the Norms promote transparent and independent monitoring systems through existing United Nations, national or international instruments that already exist or need to be created.[cxxv] In addition, they address national states who are asked to ensure implementation of them through their national administrative framework.[cxxvi] Moreover, they provide for reparations, restitution, compensation and rehabilitation for the victims of non-compliance.[cxxvii] In spite of all these positive points, the Norms suffer a number of limitations. First of all they lack specific enforcement procedures, for example guidelines regarding how damages should be calculated.[cxxviii] Furthermore, they rely on monitoring mechanisms without either specifying what agencies they are referring to or creating an obligation to establish such agencies. Likewise they fail to determine which national 
or international tribunals have the relevant jurisdiction.[cxxix] This question is particularly important when a corporation is operating under more than one jurisdiction.[cxxx] Further, the Norms do not have the status of a United Nations treaty. The major drawback is that like the OECD Guidelines, they rely on implementation by national states. This is of no help to the victims in states who are reluctant to oppose multinational corporations. In sum, there is no international legal instrument to date that effectively regulates multinational corporations. The question then is whether domestic law offers a better avenue to tackle gross environmental damage caused by multinational corporations.[cxxxi]

\section{Corporate Responsibility at the National Front}

\section{Environmental Law in the Host State}

The most appropriate and arguably the most interested state is the state in which the corporation operates and where the environmental damage has occurred, the so-called host state. It is in the state's interest to preserve the nature and the livelihood it offers for present and future generations. At the same time, the host state is also the state that is most unlikely to be willing or able to attack a multinational corporation which brings employment, revenue and economic growth.[cxxxii] The result is that the most powerful multinational corporations benefit from an informal impunity even for the grave environmental damage[cxxxiii]. This is especially true for developing countries, which are most vulnerable to the economic pressure that a corporation might put on the government. Few African courts have so far applied the constitutional provisions[cxxxiv] relating to environmental protection.[cxxxv]As Professor Ratner points out, "[c]orporations are powerful global actors that some states lack the resources or will to control." [cxxxvi] One of the consequences of this race to the bottom is the minimisation of governance, which leads to a lack of effective legislation and enforcement of existing norms.[cxxxvii] In addition, in some states effective governance and accountability are absent because they are ridden with violent conflict or civil war.[cxxxviii] For these reasons, in the eyes of many multinational corporations the risk of criminal prosecution or civil law actions remains insignificant compared to the benefits of low cost production.

At the same time, poor countries are most exposed in respect of environmental damage. Firstly, the economy of developing countries is often much more dependent on the agriculture sector than in developed countries, which makes them more vulnerable to any harm to the environment.[cxxxix] For example, the food demand in Africa is predicted to grow by 25 percent within the next ten years. [cxl] In addition, it is mostly in developing countries that one finds the most ecologically sensitive environments, which again makes these countries more exposed to environmental damage. Africa is, for example, the continent most vulnerable to desertification.[cxli] Thirdly, these countries often do not have the technologies and resources to repair the damage once the catastrophe has been caused.

Both the disincentives to regulate corporations as well as the vulnerability to environmental damage are the sad reality for many countries in Africa.[cxlii] It is therefore argued here that Africa suffers most from the lack of enforcement of environmental protection laws and the impunity of multinational corporations. Although national environmental legislation is growing in Africa, there is very little restrictive environmental law which affects corporations.[cxliii] A fine 
is not understood as motivation to change corporate policies but rather as a costly inconvenience. The immense expenditure of the legal settlement Exxon concluded after the Exxon Valdez oil spill disaster in Alaska in 1989, for example, did not seem to worry Lawrence G. Rawl, the chairman of Exxon too much. "We're talking about stretching a bill out over 10 years," he said. "It will not curtail any of our plans."'[cxliv] This 'cavalier corporate attitude'[cxlv] can be found in many companies. There are, however, examples where small countries enforce environmental laws against powerful companies. For example, in 2002 Angola fined the US oil firm ChevronTexaco \$2 $\mathrm{m}$ for causing environmental damage, [cxlvi] however, these cases are still the minority. The gas flaring in Nigeria for instance, which is causing great harm to both the environmental and human health, has continued now for decades without the government being able to stop the practice.[cxlvii] Thus, in many cases the host states are unwilling or unable to enforce environmental law against multi-national corporations even in the most severe cases of environmental damage.

\section{Civil Litigation in the Home State}

If the host state remains passive, another possible avenue could be to expect the home state of the multi-national corporation to bring them to justice even though the violation has been committed abroad.

It was the United States who first gave its courts civil jurisdiction for alleged violations outside the United States. The Alien Tort Claims Act (ACTA) 1789 allows non-citizens to bring civil action for torts that have been committed abroad.[cxlviii] Within the last few decades this act has been used a number of times to bring action regarding human rights violations that have allegedly been committed by multinational corporations.[cxlix] However, there are a number of legal obstacles, which make actions under ACTA difficult. One hurdle is the very high jurisdictional threshold of the forum non conveniens principle.[cl] This principle means that a case may be dismissed if the court deems that a foreign jurisdiction is the more appropriate forum.[cli] Thus the claimant has to show that the host country of the corporation that has been accused of environmental crimes is not in a better position to deliver justice. One of the rare examples where a domestic court rejected forum non conveniens was the English case Lubbe $v$ Cape PLC.[clii] Here the House of Lords held that although

South Africa was the more appropriate forum, the strong probability that the claimants would be unable to obtain both the legal representation and the expert evidence required to substantiate their claims in South Africa would amount to a denial of justice.[cliii]

Secondly, under the ACTA the claimants would need to show that the corporation has violated "the law of nations." [cliv] So far no United States Court has declared environmental degradation as a violation of the "law of nations".[clv] The third problem is that for most human rights violations the claimant has to show a form of state action.[clvi] In many cases this is very difficult, if not impossible for civilian claimants to get access to the relevant evidence to prove state participation.[clvii] It is equally hard for individuals to get access to evidence against a multinational corporation.[clviii] Defendants need to submit evidence which pierces the veil of 
corporate management to prove corporate involvement as well as corporate responsibility. Thus, it does not come as a surprise that actions under ACTA are rarely successful.[clix] So far, no case against a multinational corporation has been decided on its merits.[clx]

The European tort system is based on nationality and territoriality and thus less hospitable for challenging corporate behaviour abroad.[clxi] The only other country where non-citizens can bring action against human rights violations that have been committed abroad is Belgium. The Belgium Act Concerning the Punishment of Grave Breaches of International Humanitarian Law[clxii] was used in the cases of alleged forced labour in Myanmar and involvement of mistreatment in Iraq.[clxiii]

Thus civil litigation in home countries is very rarely successful and as a result an ineffective tool in targeting multinational corporations. Stephens argues that "[m]ultinational corporations have long outgrown the legal structures that govern them, reaching a level of transnationality and economic power that exceeds domestic law's ability to impose basic human rights norms."[clxiv] Even the few cases that are brought to justice do "not capture public awareness and apparently have not yet prompted significant improvements in environmental compliance."[clxv]

\section{Criminal Prosecution in the Home State}

In most countries, cases of serious environmental damage are prohibited by domestic law. In addition a number of criminal offences such as homicide or non-fatal offences against the person will also be applicable.[clxvi] Nevertheless, for a number of reasons national criminal prosecutions against multinational corporations in the home state are very rare.[clxvii]

To begin with, although many criminal justice systems around the world have now extended criminal responsibility to legal persons, [clxviii] traditionally criminal law is based on the notion that the offender is a natural person. A corporation cannot act or think itself, but rather actions and states of mind of employees need to be attributed to the corporation. In practice, it is very difficult to distinguish between the actions of the natural persons who are acting for the company and the company itself. In addition, multinational corporations are structured with a multitude of decisionmaking layers both in the home and host countries. This makes it extremely complicated to attribute a decision of a daughter company in the host country to the parent multinational corporation in the home country. A related difficulty is to identify which country has jurisdiction over the corporation. [clxix]

The second problem, and probably the more difficult one to overcome, is the question of the independency of domestic criminal justice agencies. Although judges, prosecutors and police are to a certain degree politically independent, they have to respect general policy guidelines of their government when using their discretion.[clxx] Powerful multinational corporations are in the position to exert considerable political and economic pressure on the home country and it is often not in the national interest to investigate against a business that brings in revenue, employment and prestige to the country.[clxxi] Another disincentive of prosecution for offences committed abroad is the political sensitivity of such cases. The involvement of the home state implies that the host state is not capable of dealing with the case itself because of either a lack of governance or even involvement of the host country in the crimes. States are very reluctant to encroach on the 
sovereignty of another state.[clxxii] States also shun from imposing their home regulatory standards on the host countries. [clxxiii] In addition, these cases are not high priority in the home country's public eye. In spite of growing awareness of environmental issues, citizens are still more perceptive of violent street crime than white collar crime. The public is more concerned with their safety at home rather than with the environment and living conditions of people in a distant country. As the polluted river or the destroyed forest lies thousands of miles away, it is not a popular political choice to focus police attention on these apparently remote problems.

Thirdly, the investigation against the actions of a multinational corporation abroad is incredibly resource intensive. The amount of evidence required to assess the damage to the environment, to pierce the corporate veil and to link certain corporate behaviour to the harm, is enormous. Furthermore, much of this evidence (especially witnesses) is only accessible in the host country, which means the investigation would, to a certain degree, need to be conducted abroad. Such an extensive investigation would require both substantial resources as well as transnational cooperation. As Stephens observes: "Corporations are multinational while legal systems are still largely national, creating a disconnect between international corporate structures and the law.'[clxxiv] In addition to that, the technical matter of environmental crime often poses many evidential problems. Often harm to people and environment are caused through complex biological mechanism which make it difficult to link a certain conduct (e.g. disposing of toxic waste) to environmental injury.[clxxv] In addition, the crime might be discovered only months or years later, which makes proof of causation often impossible, especially if the chemical cannot be detected in the victims' bodies any longer. [clxxvi]

In face of a limited budget for criminal investigation and the pressure to complete a high number of cases in a short amount of time, neither police nor prosecutors are inclined to allocate much of the available resources to crimes that have been committed abroad unless the victims are citizens of the state. Due to these manifold practical and legal difficulties, one can observe a lack of criminal prosecutions of multinational corporations in the home countries. In the United States, which is the home country of the majority of multinational corporations "less than one percent of all defendants facing sentencing in federal courts are corporations". [clxxvii] It will have to be seen whether the plans to start a criminal and civil litigation against BP, which President Obama announced on June 12010 ,[clxxviii] will lead to any trial.[clxxix] A promising development is the trial against the London-based oil trader, Trafigura, for alleged waste dumping which started June 2, 2010 in the Netherlands and the conviction of 8 corporate officials for the Bhopal gas disaster.[clxxx]

\section{Corporate Responsibility and Self-Regulation}

Since neither national nor international law seems able to effectively regulate the conduct of the most powerful multinational business entities, a new form of regulation -corporate self-regulationhas emerged to regulate multinational corporations to some degree. This form of soft law is based on the idea that the pressure of social awareness is often a stronger incentive than legislation to change their methods of operation. An example is the Kimberley Process Certification Scheme for so-called blood diamonds in Sierra Leone. The Kimberley Process Certification Scheme was introduced following the United Nations Security Council's call in 2000 to take "necessary measures to prohibit the direct or indirect import of all rough diamonds from Sierra Leone" to 
their respective territories.[clxxxi] This scheme enables customers to distinguish legal diamonds from those diamonds that were used to fund the violent conflict. Although the Scheme is only voluntary soft law rather than enforceable national legislation, it was highly recommended by the Security Council.[clxxxii]

The major instrument of self-regulation in dealing with corporate behaviour is the voluntary codes of conduct.[clxxxiii] Codes of conduct can be defined as "commitments voluntarily made by companies, associations or other entities which put forth standards and principles for the conduct of business activities in the marketplace".[clxxxiv] They are based on the recognition that the growing public awareness of social and environmental issues means that unsustainable production can harm the brand image to an extent that makes overly cheap production unprofitable. They therefore aim to demonstrate a notion of corporate citizenship to the consumers. Indeed corporate social responsibility is now used as a marketing strategy to promote a positive brand image. [clxxxv] According to a study by the OECD, there are now hundreds of codes of conduct in place.[clxxxvi] Although they reflect a welcome awareness of corporate responsibility, there are a number of reasons why codes of conduct do not represent an effective tool against the worst environmental damages.

First of all, these codes are not directly enforceable and there are no remedies provided for breaches. Critics claim they are nothing more than lip service[clxxxvii] used as a "mere public relations gimmick".[clxxxviii] Another problem is posed by the sheer number of different codes of conduct. Multinational corporations often operate in several different countries and work with many different business partners. Thus they have to adhere to various different codes with different standards.[clxxxix] Thirdly, there is not a uniform mechanism in place that monitors participating corporations. Questions such as whether there should be an auditing process, how independent the auditors would have to be, whether the outcomes of the audit are to be made public and how the audit can reconcile different standards of different codes, are still unresolved.[cxc] Over a third of the codes of conduct do not address the question of monitoring at all.[cxci] In addition, the growing number of codes could lead to "code fatigue" and minimise their effectiveness.[cxcii] Even some business leaders themselves favour a uniform international agreement, in order to ensure an equal standard of obligations among all companies,[cxciii] which would establish a level playing field among competing corporations.[cxciv] From the public point of view, the question arises whether a growing number of voluntary codes of conduct could encourage governments to avoid introducing binding legislation and instead rely increasingly on soft law. Therefore, rather than complementing national and international legislation, there is the danger that in the long run voluntary codes of conduct could replace them.[cxcv]

Seeing that fines are easily shrugged off by big companies as negligible extra costs of production, it is often claimed that "community pressure is the only real sanction for enforcing compliance"[cxcvi]. Nevertheless the fact remains that self-regulation is not enforceable and adherence is dependent on the cost-benefit analysis of the corporations. Bearing in mind the danger of long-term effects of environmental harm for cases of the most serious environmental damage, self-regulation is far from being an appropriate tool to fight gross environmental offences.

\section{Corporate Responsibility in International Criminal Law}


As is evident from the above discussion, national and international environmental law as well as self-regulation prove to be incapable of tackling the most serious environmental damage caused by corporations. At the same time it is extremely urgent that effective responses are found. The Stockholm Declaration made clear that the environment is a global concern that requires international collaboration.

A growing class of environmental problems, because they are regional or global in extent or because they affect the common international realm, will require extensive cooperation among nations and action by international 1 organizations in the common interest.[cxcvii]

As early as 1990 the United Nations General assembly noted that the protection of the environment is inseparable from the full enjoyment of human rights by all.[cxcviii] It is argued here that in the most severe cases of environmental damage, international criminal law should be used as ultimo ratio to sanction gross environmental damage and to end de facto impunity of multinational corporations. Thus the mainly preventive nature of international environmental law should be complemented by the essentially punitive international criminal law.

Jessup declares that "it is imperative that those who flout the right to a healthy environment incur criminal liability for their actions." [cxcix] It is interesting to observe that international law grants corporations certain human rights, but it generally does not recognize corporations as bearers of legal obligations under international criminal law.[cc] One reason for this is that it is questionable whether it is appropriate to make a corporation criminally responsible. After all, a corporation is a legal fiction rather than a moral being. Criminal law condemns blameworthy human behaviour and therefore, it is argued, the control of corporations should be left to regulatory offences. However, there are already a number of international legal instruments which create criminal liability for legal entities, such as the Basel Convention on Hazardous Wastes.[cci] It is recognised that nowadays multinational corporations play an increasing part of social life and thus must recognise social responsibility.[ccii] The major advantage of criminal law is that unlike civil law, soft law and most international instruments, it provides for conviction and punishment. An international criminal conviction of a multinational corporation would present the strongest condemnation of the international community.[cciii] Rather than leaving it to the corporation to assess whether a code of conduct would benefit their business, a criminal conviction would force every major multinational business to rethink their modes of operation and their relationships with subsidiary companies. Civil Law can also award punitive damages. However, civil law sanctions cannot address the culture of profiting from unsustainable production methods, conflict commodities and war economy and corporations are more likely to factor them in as additional costs. As Bellow and Sturtz explain: "The purpose of criminal enforcement is to shatter corporations' belief that civil fines are merely a licence to pollute or a business cost that can be passed on to consumers." [cciv] Moreover, multinational corporations are increasingly sensitive to consumer opinions. The shattering effect of the condemnation of an international conviction would be more effective than any civil law remedy. It is this deterrent effect and its preventative potential that justifies the extension of criminal responsibility to corporations. Criminal law does not only condemn certain behaviour but also educates about the values of a society. An increased criminalisation of environmental offences at international level conveys the message that serious environmental damage cannot be tolerated any longer. 
Thus extending the jurisdiction of the International Criminal Court to environmental crime not only deters or punishes individual offenders but also publicises the gravity of the problem. In addition, an international criminal prosecution against a corporation shifts responsibility from states for failure to regulate adequately to prevent environmental harm to those actors who caused the environmental damage. [ccv]

\section{The International Criminal Court}

Bruch criticises that "there remains a distinct lack of practice and international fora charged with a clear mandate to prosecute environmental crimes." [ccvi] Arguing that international criminal law should complement other national and international legal mechanisms, it is put forward here that the appropriate forum for such prosecutions would be the permanent international criminal law Court at The Hague. The establishment of a separate court for international environmental crimes[ccvii] would cause the unnecessary problems setting up a new court,[ccviii] which would include delays and additional costs. Moreover, very often environmental crimes are committed during wartime in the context of other war crimes and crimes against humanity. It would be a waste of resources to separate such cases and deal with them in separate courts. The extension of International Criminal Court crimes would also send out a strong message to national states pressing them to adopt their own domestic legislation. The International Criminal Court has already been proven to be very influential in encouraging a number of States to bring their national criminal justice systems in accordance with the Rome State and engage in international criminal prosecutions.

\section{Grave Crimes against the Environment}

The rapid development of international criminal law since the 1990s reflects the growing notion that gross human rights violations harm the whole of humanity and that impunity of the gravest perpetrators cannot be tolerated any longer. However, considering the harm serious environmental crimes cause for present and future generations, it is imperative that international criminal law should encompass these offences as well. On the other hand, any extension of the substantive jurisdiction of the International Criminal Court bears the risk of trivialisation of the core crimes. However, considering the long lasting damage that these crimes cause to the environment and the direct and indirect harm caused to present and future generations, it is argued that these crimes are on the same level as crimes against humanity, war crimes and genocide. One could argue that at least those environmental crimes that are committed during armed conflict can usually be prosecuted under the existing crime listed in Article 5 of the Rome Statute, i.e. genocide, crimes against humanity or war crimes. However, there are three problems with this approach. Firstly, for reasons of fair labelling it is important that the crimes against nature are clearly prosecuted as such and that the environmental harm is not just seen as an appendix to the harm of other protected subjects. Secondly, as was seen above, most of the relevant war crimes that could be used for environmental damage are only applicable in international rather than internal conflicts. Thirdly, Bruch warns that "even if the International Criminal Court is inclined to pursue environmental damage from an internal armed conflict, the specific standards and norms are unclear, and the danger exists that a person might be charged for something he or she did not know was a crime."[ccix] This is why in order to respect the principle of nullum crime sine legem $[\mathrm{ccx}]$ the new offence of grave crimes against the environment should be added rather than 
prosecuting environmental crime as war crime against humanity or genocide.

The call for a new international crime to reflect the seriousness and urgency of contemporary harm and destruction of the environment is not new. In the Draft Articles on State Responsibility the International Law Commission declared "that the breach of rules concerning the environment may constitute... in some cases, an international crime".[ccxi] A number of commentators have proposed the establishment of an 'ecocide' or 'geocide' treaty that would provide a parallel to the crime of genocide.[ccxii]

The gravity of the situation demands that there be a mechanism for bringing the most serious environmental offenders to heel. That mechanism must, of necessity, be the crime of geocide. It is through enforcement of such a crime that states and individuals will be able to ensure greater respect for the right to a healthy environment.[ccxiii]

Although Berat's argument draws attention to the urgency of contemporary environmental problems, this suggestion is untenable in legal terms. Obviously the offender will not have been able to complete the actus reus of destroying the environment to such an extent that it incapable of sustaining life. Thus, such an offence would need to be structured like genocide, i.e. proscribing certain acts that the offender committed with the intention to destroy the planet. Realistically, it would be difficult to find cases where an offender had such an intention. Moreover, most of the current cases of environmental damage are not in themselves sufficient to destroy the whole globe. Rather it is the computation of different acts of destruction and pollution around the world that endangers this planet. Thus the term geocide helps to draw attention to the gravity and urgency of the problem but not as a legal mechanism.

Instead it is proposed here that the Rome Statute should include the new offence of grave crimes against the environment. McLaughlin proposes the following core of a definition while acknowledging that the details would need to be elaborated on: [ccxiv]

For the purpose of this Statute, "environmental crimes" means the intentional or reckless commission by an individual or individuals, regardless of the status of the act under any applicable domestic regulation, of any of the following acts:

(a) directly causing large scale or serious pollution of the:

1. sea;

2. atmosphere;

3. [other relevant sites/mediums of pollution]; or

(b) conducting an activity, the widespread harmful effects of which should have been contemplated by a reasonably prudent individual; or

(c) breaching an obligation within the established framework of international law, the observance of which is recognized as essential for the protection of the environment; or

(d) aiding or abetting any of the above acts.

There are some deficiencies with this definition. First of all, there seems to be a considerable 
overlap between (a) and (b). Furthermore, (c) does not seem to be workable as not all states have ratified all international environmental treaties, which would mean different individuals would be measured according to different standards. Besides, if this offence would be included in the Rome Statute (d) would be covered by the modes of participation in Article 25(3)(c) Rome Statute. Finally, the restriction of the mens rea to intention only seems to set the threshold too high. Although McLaughlin's definition has many positive aspects here, a different approach is suggested.

\section{Structure}

It is argued here that, leaning on the model of Articles 6-8 Rome Statute, the new offence should list specific prohibited results whose causation leads to criminal responsibility. Instead of a referral to other instruments it is suggested that obligations on which the member states can agree should be listed in the definition of the offence.[ccxv] However this list could be rooted in international environmental law norms, for example international treaties covering maritime pollution, fresh water pollution, desertification, deforestation, destruction of wildlife and others.

\section{Threshold}

It is important to stress that the International Criminal Court should only prosecute the offence of grave crimes against the environment if it is of the same seriousness as the other crimes in the Rome Statute. Hence this new offence would include a high threshold to limit the Court's jurisdiction to the most severe cases. Relevant criteria could include harm caused to human beings (direct harm such as severe bodily harm or death or non-immediate harm such as slowly developing illnesses, stillbirths or loss of fertility), the scale of damage to environment and longevity of the environmental harm. One question is whether the member parties of the Rome Statute would be willing to extend the Court's jurisdiction. As was seen above, there are only very few binding international environmental legal instruments. In general, international environmental law is based on negotiated soft law far from any obligations of customary law. However if this offence was to be restricted to a very high threshold of clearly foreseeable and unjustifiable risk and a high threshold of harm, it can be expected that the vast majority of member states and maybe even non-member states would sign up to the new offence.

\section{Actus Reus}

Unlike section (b) in Laughlin's model, the definition of the offence should only include result crimes rather than conduct crimes. However the term 'may be expected to cause' makes it clear that danger of harm is a sufficient result and the actual damage, which might manifest itself years after the commission, does not need to be proven by the prosecution, as long as the danger is patent. Thus the use of landmines in a wild forest would be sufficient for criminal prosecution even before direct harm of wildlife can be shown.

An aspect that is of crucial importance is the question of causation. In many cases it might be difficult to prove beyond reasonable doubt that a certain action by a corporation is the sole cause of the environmental damage. Therefore it is suggested to include the threshold of "substantial causation'. It will then be for the Prosecution to rebut any claim of the defendant that other factors contributed significantly to the environmental harm. 


\section{Mens Rea}

As a general rule the required mental element in the Rome statute is intent or knowledge,[ccxvi] but the concept of command responsibility includes recklessness.[ccxvii] While environmental damage in the context of armed conflict is very often part of the intended attack, in peacetime the damage is not wanted in itself but accepted as a side-effect of cost-effective production methods. In order to include the most serious crimes in both wartime and peacetime, it is suggested that the mens rea threshold should be lowered to include objective recklessness. Borrowing from the Additional Protocol I, the offence would prohibit acts "which are intended, or may be expected, to cause widespread, long-term and severe damage to the natural environment." [ccxviii] That means the offender is criminally responsible if they commit the actus reus while the prohibited results were clearly foreseeable for a reasonable person.

\section{Corporate Criminal Responsibility}

In order to use the International Criminal Court for corporate environmental crimes, Article 25 Rome Statute, which provides for jurisdiction over natural persons, would need to be extended to include criminal responsibility of legal persons, such as multinational corporations. Already one can observe a growing awareness of the supporting crimes which make human rights violations possible. Rather than only the combatants and the masterminds behind the offences the International Criminal Court starts looking at financial causes. For example, Prosecutor Luis Moreno Ocampo has indicated that he might investigate persons involved in the trade of so-called blood diamonds.[ccxix] At the same time the link between war crimes and corporations which profit in war economies has long been recognised; there have been calls for corporate sanctions from World War II[ccxx] to Vietnam.[ccxxi] Fisse and Braithwaite have shown that corporations are not simply the sum of their employees. They develop an ethos beyond that of the individuals who act for them.[ccxxii] In addition, if only individuals were to be convicted and punished, it would be too easy for corporations to use them as scapegoats[ccxxiii] or single them out as "a few bad apples". In view of the gross human rights violations[ccxxiv] and environmental damage that corporations cause, which are to concern of the whole international community, the Rome Statute need to be amended and personal jurisdiction extended to legal persons.

However, there is strong resistance against the extension of the Court's jurisdiction over legal persons. A corporation does not have any physical existence. It is not an agency that is acting and thinking but merely a legal fiction. Many argue that criminal law is punishing blameworthy conduct and that assuming moral behaviour for a corporation is taking this fiction too far. The primary purpose of corporations is to maximise profit rather than engaging in social welfare or environmental protection.[ccxxv] As Stephens explains:

Profit-maximization, if not the only goal of all business activity, is certainly central to the endeavour. And the pursuit of profit is, by definition, an amoral goal—not necessarily immoral, but rather morally neutral. An individual or business will achieve the highest level of profit by weighing all decisions according to a self-serving economic scale. Large corporations magnify the consequences of the amoral profit motive.[ccxxvi]

Beyond the question of moral blameworthiness of corporations there is however another pressing reason to include legal persons in the reach of international criminal law. It is the urgency of the 
need to deter future reckless behaviour that potentially damage the planet and mankind for many generations that requires putting an end to the de facto immunity, which multinational corporations enjoy for the most serious environmental damage. More discussion and negotiation between Member States would be needed to agree on a concept of corporate criminal responsibility to establish principles under which the actions and mental states of individuals could be attributed to a company (e.g. identification theory or vicarious liability). It is here suggested that a corporation is responsible for conduct which was part of explicit or implicit company policy, or committed with knowledge of senior management.

\section{Penalties}

Article 77 of the Rome Statute which provides for fines only in addition to imprisonment would need to be amended to include fines-only penalties for corporations. Circumstances which the Court should need to take into consideration when finding the appropriate sentence would include the extent of the damage, the nature of the affected nature (e.g. importance to human survival, rarity etc), the degree of recklessness of the corporation, the extent of attempts to clear the damage, previous behaviour, size and wealth of the corporation and profit realised by the offence.[ccxxvii]

An element which would be new in international criminal law would be to allow for special mitigating circumstances for this crime. In the United States, the Environmental Protection Agency indicates that activities such as self-policing, self-auditing and voluntary disclosure of environmental violations will be viewed as mitigating factors in the exercise of criminal environmental enforcement discretion.[ccxxviii] This model could be used in international criminal environmental law. A corporation that can show it has implemented policies of selfauditing and disclosure will be able to demonstrate that it does not fall below the reasonable standard required. An example of this would be if it had no knowledge of certain risks and no foresight. It could also be used as mitigating circumstances when assessing the penalty after a conviction. If case law developed where corporate policies played a role in evaluating both guilt and blameworthiness, this would be a great incentive for all corporations to increase transparency and introduce policies of more care.

\section{Special Chamber}

The adoption of a new offence of grave crimes against the environment would change the nature of the International Criminal Court. Although genocide and crimes against humanity can be committed in peacetime, the situations the International Criminal Court will deal with will be of extreme violence.[ccxxix] Environmental crimes could be committed without the context of mass violence. At the same time the evaluation of the facts might require a greater specific knowledge of environmental law. It is thus proposed to establish a new Chamber dedicated to environmental crimes.

\section{Conclusions}

A point has been reached in history when we must shape our actions throughout the world with a more prudent care for the environmental consequences [...] To defend and improve 
the human environment for present and future generations has become an imperative goal for mankind--a goal to be pursued together with, and in harmony with, the established and fundamental goals of peace and of worldwide economic and social development.[ccxxx]

One should not overlook the great benefits multinational corporations generally bring to their host and home countries. However, the great economic power that corporations have is not separable from great responsibility. In those cases where multinational corporations abuse this power to engage in conduct which causes grave damage to the environment, and national states are not willing or able to prosecute, the international community needs to end this de facto immunity. "Although critics have characterized the present degrading of the environment as a sin which generations will not forgive"'[ccxxxi] we have not yet managed to find an effective way to reconcile our wish for economic growth with sustainable production methods. Neither national law of the host and home countries of corporations nor international law nor self-regulation has proven to be effective in fighting the worst preventable environmental damage. International criminal law is not the panacea for environmental protection but it could play a vital role, and it is time that all possible avenues are explored. The adoption of a new international crime prosecuted before the International Criminal Court is one of these possible routes. 
[i] World Commission on Environment and Development, Our Common Future, A/42/427. Our Common Future: Report of the World Commission on Environment and Development available at http://www.un-documents.net/ocf-ov.htm last visited April 30, 2010.

[ii] In many societies Nature is either seen as divine itself, the expression of the divine or at least as creation of the divine which human beings are to guard.

[iii] Speth is speaking of the "growth fetish". James Gustave Speth, International environmental Law: Can it Deal with the Big Issues? (2004) 28 Vermont Law Review 779, at 783.

[iv] This term includes desertification, desert-encroachment, aridiation and zerotisation. Leslie C. Clark, A Call to Restructure Existing International environmental Law in Light of Africa's Renaissance: The United Nations Convention to Combat Desertification and the New Partnership for Africa's Development (NEPAD) (2003) 27 Seattle University Law Review 525, at 529.

[v] Although the international community showed some concern of the environment when celebrating the first Earth Day in 1970.

[vi] For example 20.4 million hectares of tropical forests are cut down each year in Asia, Africa, and Latin America. Ethan H. Jessup, Environmental Crimes and Corporate Liability: The Evolution of the prosecution of 'Green' Crimes by Corporate Entities (1999) 33 New England Law Review 721 at

725.

[vii] In addition for clearing environmental disasters many states are dependent on the resources and technologies from other countries. Robert McLaughlin, Improving Compliance: Making Non-State International Actors

Responsible for Environmental Crimes (2000)11 Colorado Journal of International Environmental Law and Policy 377 , at 387.

[viii] Although much more has to be done here.

[ix] When analysing to what extent existing international law norms are effective in dealing with gross environmental damage it is necessary to distinguish between peacetime and wartime situations, due to different legal regimes applying. Sometimes these groups overlap however, e.g. Bougainville Island, where the exploitation of mining was closely related to the civil unrest.

[x] Geoffrey Palmer, New Ways to Make International Environmental Law (1992) 86 American Journal of International Law 259, at 262.

[xi] 1911 Convention Between the United States and Other Powers Providing for the Preservation and Protection of Fur Seals July 7, 1911, 37 Stat. 1542, 5 Martens Nouveau Recueil (3d ed.) 720 (entered into force Dec. 15, 1911).

[xii] Convention for the Regulation of Whaling, Sept. 24, 1931, T.S. No. 880, 155 L.N.T.S. 349 (entered into force Jan. 16, 1935), International Agreement for the Regulation of Whaling: June 8, 1937, 52 Stat. 1460, 190 L.N.T.S. 79, 32 U.N.T.S. 404, (entered into force May 7, 1938),

International Convention for the Regulation of Whaling: Dec. 2, 1946, 62 Stat. 1716, 161

U.N.T.S. 72 (entered into force Nov. 10, 1948).

[xiii] Convention for the Regulation of the Meshes of Fishing Nets and the Size Limits of Fish, Apr. 5, 1946, 231

U.N.T.S. 199 (entered into force Apr. 5, 1953).

[xiv] Agreement on the Conservation of Polar Bears, Nov. 15, 1973, 27 U.S.T. 3918, (entered into force May 26, 1976).

[xv] Convention on Nature Protection and Wildlife Preservation in the Western Hemisphere, Oct. 12, 1940, 56 Stat. 1354, 161 U.N.T.S. 193, (entered into force Apr. 30, 1942).

[xvi] Nov. 8, 1933, 172 L.N.T.S. 241 (entered into force Jan. 14, 1936).

[xvii] Mar. 6, 1973, 993 UNTS 243 (entered into force 1 July 1975).

[xviii] May 12, 1954, 12 U.S.T. 2989, 327 U.N.T.S. 3, (entered into force July 26, 1958).

[xix] Nov. 2, 1973, I.M.C.O. Doc. MP/CONF/WP.35.

[xx] Nov. 13, 1979, 18 ILM 1442(1979).

[xxi] Institutional and Financial Arrangements for International Environmental Cooperation, GA Res. 2997, 27 UN

GAOR Supp. (No. 30) at 43, UN Doc. A/8730 (1972).

[xxii] Stockholm Declaration on the Human Environment, adopted by the UN Conference on the Human

Environment at Stockholm, June 16, 1972, Section I of Report of the United Nations Conference on the Human 
Environment, UN Doc. A/ CONF.48/14 and Corr.1 (1972), reprinted in 11 ILM 1416 (1972).

[xxiii] Palmer supra note 10, at 267.

[xxiv] Vienna Convention for the Protection of the Ozone Layer, Mar. 22, 1985, UN Doc. UNEP/1G.53/Rev.1, S. TREATY DOC. NO. 9, 99th Cong., 1st Sess. (1985) (entered into force Sept. 22, 1988).

[xxv] Palmer supra note 10, at 259.

[xxvi] Ibid.

[xxvii] Ibid., at 263.

[xxviii] Jessup supra note 6, at 722 .

[xxix] Lynn Berat, Defending the Right to a Healthy Environment: Toward a Crime of Geocide in International Law

(1993) 11 Boston University International Law Journal 327, at 328.

[xxx] Palmer supra note 10, 264 citing Rt. Hon. Geoffrey Palmer, General Debate Statement of New Zealand

Government, UN Doc. A/ 44/PV.15, at 61, 76 (1989).

[xxxi] Palmer supra note 10, at 263.

[xxxii] Marc A. Levy et al., Improving the Effectiveness of International Environmental Institutions, in Institutions

for the Earth 397, 398-99 (Peter M. Haas et al. eds., 1993).

[xxxiii] Carl E. Bruch, All's Not Fair in (Civil) War: Criminal Liability for Environmental

Damage in Internal Armed Conflict (2001) 25 Vermont Law Review 695, at 699.

[xxxiv] Meredith DuBarry Huston, Wartime Environmental Damages: Financing the Cleanup (2002) 23 University of

Pennsylvania Journal of International Economic Law 899.

[xxxv] Bruch supra note 33, at 699.

[xxxvi] DuBarry Huston supra note 34, at 910.

[xxxvii] Tania Marie Proechel, Solving International Environmental Crimes: The International Environmental Military Base Reconstruction Act - A Problem, A Proposal, And a Solution (2007) 29 Loyola of Los Angeles International and Comparative Law Review 121.

[xxxviii] Bruch supra note 33, at 698.

[xxxix]Environmental Rape, Human Exploitation And Price Fixing Take the Sparkle Out of Her Diamonds, world catastrophe map, available at http://www.catastrophemap.com/diamond.html (last visited May 2010).

[xl] Report of the Panel of Experts Appointed Pursuant to UN Security Council Resolution 1306 (2000), Paragraph

19, in Relation to Sierra Leone, U.N. Doc. S/2000/1195 (2000), available at

http://www.un.org/Docs/sc/committees/Liberia2/470e.pdf (last visited May 2010).

[xli] Diane Marie Amann, Capital Punishment: Corporate Criminal Liability for Gross Violations of Human Rights, (2001) 24 Hastings International and Comparative Law Review, 327 at 330. Impact of Armed Conflict on Children: Report of the Expert of the Secretary-General, Ms. Graça Machel, Submitted Pursuant to General Assembly Resolution 48/157, U.N. GAOR, 51st Sess., Agenda Item 108 PP 27, 47, U.N. Doc. A/51/306 (1996).

[xlii] On conflict diamonds see also Lucinda Saunders, Rich And Rare Are The Gems They War: Holding De Beers Accountable For Trading Conflict Diamonds (2001) 24 Fordham International Law Journal 1402.

[xliii] Coltan is a precious mineral used in cell phones, computer chips, nuclear reactors, and PlayStations.

[xliv] For a sample of companies importing minerals from the Democratic Republic of the Congo see Report of the Panel of Experts on the Illegal Exploitation Of Natural resources and Other Forms of Wealth of the Democratic Republic of the Congo, U.N. Doc.S/2001/357 (April 12, 2001) annex 1, p 184 available at http://www.undemocracy.com/S-2001-357.pdf (last visited May 1010). For details on how the impact of the report see Fauchald/Stigen, Corporate Responsibility before International Institutions (2009) 40 George Washington International Law Review 1025 at 1028.

[xlv]Information for Action, The Impact Of War and Weapons On Humans And The

Environment, available at http://www.informaction.org/cgi-

bin/gPage.pl?menu=menua.txt\&main=weapons_examples.txt\&s=Weapons (last visited May

2010).

[xlvi] Bruch supra note 33, at 698.

[xlvii] FAFO-Report no. 467, Business and International Crimes - Assessing the Liability of Business Entities for Grave Violations of International Law (International Peace Academy) 2004 accessible on http://www.fafo.no/pub/rapp/467/467.pdf at 6 (last visited May 2010), at 12.

[xlviii] The involvement of business entities making profit by cooperating with oppressive regimes is not a new 
phenomenon. During World War II no less than several hundred companies used slave labour provided by the Nazis. Anita Ramasastry, Corporate Complicity: from Nuremberg to Rangoon - An Examination of Forced Labour Cases and their Impact on the Liability of Multinational Corporations, 20 Berkeley Journal of International Law (2002), 91at 105ff. For civil suits for violations of human rights see also Craig Scott, Translating Torture into Transnational Tort: Conceptual Divides in the Debate on Corporate Accountability for Human Rights Harm, in Torture as Tort: Comparative Perspectives on the Development of Transnational Human Rights Litigation (Oxford: Hart Publishing, 2001) 46-63.

[xlix] FAFO-Report supra note 47.

[1] Saeed Shah, Weir Group Stands Firm Over Sudan, (2001) The Independent, Aug. 23, available at http://news.independent.co.uk/business/news/article211561.ece (last visited May 2010).

[li] Gilles Carbonnier, Corporate Responsibility And Humanitarian Action - What Relations Between the Business and Humanitarian Worlds? (2001) 83/844 International Review of the Red Cross 947 at 950.

[lii] Fauchald/Stigen, Corporate Responsibility before International Institutions (2009) 40 George Washington International Law Review 1025 at 1028.

[liii] DuBarry Huston supra note 34, 929. As these conventions are regarded as customary law, even states which were not originally parties to the conventions are bound by them.

[liv] Aaron Schwabach, Environmental Damage Resulting from the NATO Military Action Against Yugoslavia (2000) 25 Columbia Journal of Environmental Law 117, at 118.

[lv] Bruch supra note 33, at 702.

[lvi] Convention Between the United States and Other Powers Respecting the Laws and Customs of War on Land, Oct. 18, 1907, Annex Article 55, 36 Stat. 2277, 2309, 205 Consol. T.S. 277.

[lvii] DuBarry Huston supra note 34, at 904.

[lviii] Article 23(g) reads “To destroy or seize the enemy's property, unless such destruction or seizure be imperatively demanded by the necessities of war".

[lix] DuBarry Huston supra note 34, at 903.

[lx] "Two days after the beginning of the 1990 Persian Gulf War bombing campaign in Iraq, the Iraqis opened the flow of oil into the Persian Gulf. By the end of the war, 600 miles of sea surface were covered by an oil slick containing somewhere between four and six million barrels of oil and 300 miles of coastline were contaminated by the deliberate spill. Iraq then set fire to or otherwise damaged between 500 and 800 oil producing Kuwaiti wells. During May and June of 1990, "4.5 million barrels of oil per day were lost to the fires." Despite the allied forces' rapid response to Iraq's actions, Kuwait's flora and fauna, air, soil, and water suffered devastating effects:". DuBarry Huston supra note 34, at 909.

[1xi] Geneva Convention for the Amelioration of the Condition of the Wounded and Sick in Armed Forces in the Field, Aug. 12, 1949, 6 U.S.T. 3114, 75 U.N.T.S. 31 (Geneva I); Geneva Convention for the Amelioration of the Condition of Wounded, Sick and Shipwrecked Members of Armed Forces at Sea, Aug. 12, 1949, 6 U.S.T. 3217,75

U.N.T.S. 85 (Geneva II); Geneva Convention Relative to the Treatment of Prisoners of War, Aug. 12, 1949, 6 U.S.T. 3316, 75 U.N.T.S. 135 (Geneva III); Convention (IV) Relative to the Protection of Civilian Persons in Time of War, opened for signature Aug. 12, 1949, 6 U.S.T. 3316, T.I.A.S. No. 3365, 75 U.N.T.S. 135 (entered into force Oct. 21 1950) (Geneva IV).

[1xii] As with the Hague Convention it is however questionable whether the term property can be interpreted to include natural assets not in specific ownership.

[1xiii] Article 50 Geneva Convention I; Article 51 Geneva Convention II; Article 147 Geneva Convention IV.

[lxiv] Bruch supra note 33, at 709.

[lxv] Articles 146 and 148 .

[lxvi] DuBarry Huston supra note 34, at 903.

[lxvii] 200 million gallons of the herbicides Agent Orange, Agent white and Agent Blue were sprayed on Vietnam and Laos. Schwabach supra note 54, at 126.

[lxviii] Article II.

[lxix] Protocol Additional to the Geneva Conventions of 12 August 1949, Relating to the Protection of Victims of International Armed Conflicts (Protocol I), opened for signature Dec. 12, 1977, 16 I.L.M. 1391.

[lxx] Protocol Additional to the Geneva Conventions of 12 August 1949, and Relating to the Protection of Victims of Non-International Armed Conflicts (Protocol II), June 8, 1977, 1125 U.N.T.S. 609. 
[lxxi] Convention on the Prohibition of Military or Any Other Hostile Use of Environmental Modification Techniques, opened for signature May 18, 1977, 31 U.S.T. 333,1108 U.N.T.S. 151. [lxxii] Article 35(3) reads: "It is prohibited to employ methods or means of warfare which are intended, or may be expected, to cause widespread, long-term and severe damage to the natural environment."

[lxxiii] Article 55(1) reads: "Care shall be taken in warfare to protect the natural environment against widespread, long-term and severe damage. This protection includes a prohibition of the use of methods or means of warfare which are intended or may be expected to cause such damage to the natural environment and thereby to prejudice the health or survival of the population."

[lxxiv] DuBarry Huston supra note 34, at 905.

[lxxv] Bruch supra note 33, at 703.

[lxxvi] DuBarry Huston supra note 34, at 907.

[lxxvii] Bruch supra note 33, at 711 .

[lxxviii] Ibid at footnote 50 .

[lxxix] Statute of the International Tribunal for Rwanda, S.C. Res. 49/955, U.N. Doc. S/Res/955/Annex (Nov. 8, 1994).

[lxxx] Article 4.

[lxxxi] DuBarry Huston supra note 34, at 906.

[lxxxii] Article II.

[1xxxiii] Article I (1): Each State Party to this Convention undertakes not to engage in military or any other hostile use of environmental modification techniques having widespread, long-lasting or severe effects as the means of destruction, damage or injury to any other State Party.

[lxxxiv] For example the tactic of the Untied States to use tractors with cutting blades to clear 750,000 acres of land in Vietnam is not covered by ENMOD.

[lxxxv] Michael D. Diederich, Jr., "Law of War" and Ecology-A Proposal for a Workable Approach to Protecting the Environment Through the Law of War, (1992) 136 Military Law Review 137, at 152.

[lxxxvi] Bruch supra note 33, at 710.

[lxxxvii] (Opened for signature 18 September 1997) 36 International Legal Materials 1507 (entered into force 1 March 1999).

[lxxxviii] Article 1 (entered into force Dec. 3, 1998) 35 International Legal Materials 1209. [lxxxix] June 17, 1925, 26 UST 571.

[xc] Convention for the Protection of Cultural Property in the Event of Armed Conflict, May 14, 1954, 249 U.N.T.S.

215 (entered into force Aug. 7, 1956).

[xci] Article 1

[xcii] Bruch supra note 33, at 712 .

[xciii] Article 4(2)

[xciv] Protocol for the Protection of Cultural Property in the Event of Armed Conflict, May 14, 1954, 38 International Legal Materials 769 (entered into force Aug. 7, 1956).

[xcv] Article 6.

[xcvi] Article 7.

[xcvii] Article 22(1).

[xcviii] Bruch supra note 33, at 712.

[xcix] For a discussion of the environmental damage caused by NATO bombing in Former Yugoslavia see

Schwabach, supra note 54 .

[c] The International Tribunal for the Prosecution of Persons Responsible for Serious Violations of International Humanitarian Law Committed in the Territory of the Former Yugoslavia Since 1991 (ICTY), SC Res 827, UN SCOR, 48th session, 3217th meeting, [1], UN Doc S/Res/827 (1993).

[ci] The International Criminal Tribunal for the Prosecution of Persons Responsible for Serious Violations of International Humanitarian Law Committed in Rwanda (ICTR), SC Res 955, UN SCOR, 49th session, 3453rd meeting, [1], UN Doc S/Res/955 (1994).

[cii] Articles 2(d), 3(b) Statute of The International Tribunal For The Former Yugoslavia U.N.

Doc. S/RES/827 art. 6 (1993).

[ciii] Article 4(f) ICTR Statute. 
[civ] U.N. Doc. A/CONF.183/9, available at http://untreaty.un.org/cod/icc/statute/romefra.htm.

[cv] Bruch supra note 33, at 704.

[cvi] For example it was claimed that oil exploration and development in the Ecuadorian Amazon would cause such damage to the environment that the indigenous peoples living in this part of the Amazon would be endangered and that such a project would constitute ethnocide. This case could not be legally described as genocide which requires intention to destroy the groups, recklessness is not sufficient. Bruch supra note 33, at 727

[cvii] Bruch supra note 33, at 715.

[cviii] Convention on International Trade in Endangered Species of Wild Fauna and Flora, Washington, D.C., Mar. 3, 1973, 27 U.S.T. 1087 (entered into force July 1, 1975).

[cix] Basel Convention on the Control of Transboundary Movements of Hazardous Wastes and Their Disposal, Basel Mar. 22, 1989, 28 I.L.M. 657 (entered into force May 5, 1992). For a discussion of the role of the Basel Convention in Africa see Andrew Webster-Main, Keeping Africa out of the Global Backyard: A Comparative Study of the Basel and Bamako Conventions (2002) 26 Environmental Law and Policy Journal 65.

[cx] Bruch supra note 33, at 716.

[cxi] Bruch supra note 33, at 698.

[cxii] Emeka Duruigbo, Corporate Accountability and Liability for International Human Rights Abuses: Recent

Changes and Recurring Challenges (2008) 6 Northwestern University Journal of International Human Rights 222, at $* 2$.

[cxiii] For the discussion of whether there is a 'human right to an environment of good quality' see Justice Susan Glazebrook, Human Rights and the Environment (2009) 40 Victoria University of Wellington Law Review 293. [cxiv] Developments in the Law-Corporate Liability for Violations of International Human Rights Law,(2001) 114 Harvard Law Review 2025, at 2030-31 (2001).

[cxv]http://www.oecd.org/dataoecd/56/36/1922428.pdf. (last visited May 2010). The Guidelines are a part of the Declaration on International Investment and Multinational Enterprises available at http://www.itcilo.it/actrav/actrav-english/telearn/global/ilo/guide/oecddec.htm (last visited May 2010).

[cxvi] Barnali Choudhury, Beyond the Alien Tort Claims Act: Alternative Approaches to Attributing Liability to Corporations for Extraterritorial Abuses, 26 Northwestern Journal of International Law and Business, 43 (2005) at 64. [cxvii] Available at http://www.ilo.org/public/english/employment/multi/download/english.pdf (last visited May 2010).

[cxviii] Available at http://www.unglobalcompact.org/AboutTheGC/index.html. (last visited May 2010). [cxix] The tenth principle was added 24 June 2004, during the UN Global Compact Leaders Summit.

[cxx] 1. Businesses should support and respect the protection of internationally proclaimed human rights.

2. Make sure they are not complicit in human rights abuses.

3. Businesses should uphold the freedom of association and the effective recognition of the right to collective bargaining;

4. The elimination of all forms of forced and compulsory labour;

5. The effective abolition of child labour;

6. Eliminate discrimination in respect of employment occupation.

7. Business should support a precautionary approach to environmental challenges;

8. Undertake initiatives to promote greater environmental responsibility;

9. Encourage the development and diffusion of environmentally friendly technologies.

10. Businesses should work against corruption in all its forms, including extortion and bribery. [cxxi] U.N. ESCOR, 55th session, 22nd meeting. at Agenda Item 4, U.N. Doc.

E/CN.4/Sub2/2003/12/Rev.2 (2003). See also Commentary on the Norms on the Responsibilities of Transnational Corporations and Other Business Enterprises with Regard to Human Rights, U.N. Doc. E/CN.4/Sub.2/2003/38/Rev.2 (2003).

[cxxii] Norms preamble para 14.

[cxxiii] Supra note 121.

[cxxiv] Norms para 15.

[cxxv] Norms para 16.

[cxxvi] Norms para 17. 
[cxxvii] Norms para 18.

[cxxviii] Choudhury, supra note 116, at 66.

[cxxix] Norms para 18.

[cxxx] This is especially relevant for the question of forum non-convenience, see below.

[cxxxi] For other regulatory avenues such as the united States Clean Diamond Act 2004 see Edward R Fluet, Conflict

Diamonds: U.S. Responsibility and Response (2005-2006) 7 San Diego International Law Journal 103.

[cxxxii] Jan Wouters and Cedric Ryngaert, Litigation for Overseas Corporate Human Rights Abuses in The European Union: The Challenge of Jurisdiction (2009) 40 George Washington International law Review 939.

[cxxxiii] J. Donelly-Saalfield, Irreparable Harms: How the Devastating Effects of Oil Extraction in Nigeria Have Not Been Remedied by Nigerian Courts, The African Commission, or U.S. Courts (2009) 15 Hastings West-Northwest journal of Environmental Law and Policy 371.

[cxxxiv] An example where a court did consider the constitution in regards to the environment is the case of Joseph D. Kessy v DarEes Salaam City Council where citizens sought action against the city council for dumping garbage in their suburb. Jospeh D. Kessy v Dare Es Salaam City Council, Civil Case No 299 of 1988 (high Court of Tanzania at Dar Es Salaam, September 9,1991). However, it is usually not possible to claim human rights against private legal persons.

[cxxxv] Carl Bruch, Wole Coker, Chris VanArsdale, Constitutional Environmental Law: Giving Force to Fundamental Principles in Africa (2001) 26 Columbia Journal of Environmental Law 131, 162. The environment is also enshrined in Article 24 of the African Charter on Human and Peoples' Rights (27 June 1981) 1520 UNTS 217.

[cxxxvi] Steven R. Ratner, Corporations and Human Rights: A Theory of Legal Responsibility, 111 YALE L. J. 443, 461 (2001).

[cxxxvii]Ole Kristian Fauchald \& Jo Stigen, Corporate Responsibility before International Institutions (2009) 40 George Washington International Law Review 1025 at 1028.

[cxxxviii] FAFO report supra note 47 at 6.

[cxxxix] Approximately 80\% of Africa's population depends on agriculture for survival. Chris N. Okeke, Africa and the Environment, (1996) 3 Annual Survey of International and Comparative Law 37, at 43.

[cxl] Speth supra note 3, at 781 .

[cxli] Clark supra note 4, at 5526.

[cxlii] 20 of the 30 least developed countries are in Africa.

[cxliii] For example the Federal Environmental Protection agency Decree of Nigeria which was praised as "Nigeria's most comprehensive national enactment on matters of environment since independence" provides only for very small fines.

[cxliv] N.Y. Times, Mar. 17, 1991, $\S 4$, at 5, col. 5. A few hours later, Exxon stock closed at $\$ 57.25$, up $\$ 1$ on the New York Stock Exchange.

[cxlv] Jessup supra note 6, at 725 .

[cxlvi] BBC Business news 1 July, 2002, available at: http://news.bbc.co.uk/1/hi/business/2077836.stm

[cxlvii] Andrew Walker, Nigeria's gas profits 'up in smoke', available at

http://news.bbc.co.uk/1/hi/world/africa/7820384.stm (last visited May 2010). This is in spite of the fact that this practice has been outlawed in Nigeria as early as in 1984. Donnelly-Saalfield supra note 133, at 374 .

[cxlviii] 28 USC $\$ 1350$

[cxlix] For example see, e.g., Abebe-Jira v. Negewo, 72 F.3d 844 (11th Cir.1996); Kadic v. Karadzic, 70 F.3d 232 (2d Cir.1995); In Re Estate of Ferdinand Marcos, 25 F.3d 1467 (9th Cir.1994); Tel-Oren v. Libyan Arab Republic, 726 F.2d 774 (D.C.Cir.1984); Filartiga v. Pena-Irala 630 F.2d 876; Xuncax v. Gramajo, 886 F.Supp., Doe I v. Unocal Corp., 395 F.3d 932.

[cl] For a criticism of the doctrine see Kathryn Lee Boyd, The Inconvenience of Victims: Abolishing Forum Non Conveniens in U.S. Human Rights Litigation, (1998) 39 Virginia Journal of International Law 41, at 46.

[cli] Saunders supra note 44, at 1453.

[clii] Lubbe v. Cape PLC, [2000] 1 W.L.R. 1545 (H.L.). The over 3000 claimants sought damages for personal injury allegedly suffered as a result of exposure to asbestos and its related products in South Africa from the business incorporated in England.

[cliii] Lubbe v. Cape Plc. [2000] 4 All E.R. 268. Another example is Connelly v RTZ Corp Plc (No.2), [1997] 4 All E.R. 335 in which the court rejected the claim that Namibia was the appropriate forum but which was later struck down on limitation grounds. However these are English cases and not binding on American courts applying ACTA. [cliv] Section 1350 of ACTA, Chapter 85, Title 28, Part IV.

[clv] Donnelly-Saalfield supra note 133, at 394. 
[clvi] According to the so-called the "colour of law" jurisprudence adopted by U.S. courts under 42 U.S.C. section 1983, Kadic v Karadzic 70 F.3d 232 C.A.2 (N.Y.),1995, at 245.

[clvii] E.g. the cases Unocal II, 110 F. Supp. 2d 1294, 1305 (C.D. Cal. 2000); and Beanal v. Freeport-McMoRan, 969 F. Supp. 362, 373-74 (E.D. La. 1997) were dismissed because the claimants could not show the required level of State action.

[clviii] Saunders supra note 44, at 1453.

[clix] See for example Amlon Metals, Inc. v. FMC Corp., 775 F. Supp. 668 (S.D.N.Y. 1991); Aguinda v. Texaco, Inc., 1994 U.S. Dist. LEXIS 4718 at *1-2 (S.D.N.Y. Apr. 11, 1994); Aguinda v. Texaco, 303 F.3d 470 (2d Cir. 2002); Beanal v. Freeport McMoRan, 197 F.3d 161, 167 (5th Cir. 1999); Flores v. Southern Peru Copper, 343 F.3d 140, 161 (2d Cir. 2003).

[clx] Choudhury supra note 121, at 44.

[clxi] Wouters/Ryngaert supra note 132, at 942. However, this practice might change with Article 2 of the EC Council Regulation on Jurisdiction in Civil and Commercial Matters (Brussels Regulation) which regulates that any corporation domiciled in an EU member state can be sued in this state. Council Regulation 44/2001 O.J. (L12) 3 (EC). However, there is no case law yet of European-based multinational corporations regarding violations abroad.

[clxii] For an English translation of the Act, see 38 International Legal Materials 918 (1999).

[clxiii] Choudhury supra note 121, at 46.

[clxiv] Beth Stephens, The Amorality of Profit: Transnational Corporations and Human Rights, (2002) 20 Berkeley Journal of International Law 45, at 54.

[clxv] Robert W. Adler and Charles Lord, Environmental Crimes: Raising the Stakes, 59 George Washington Law Review 781.

[clxvi] For example in the famous American CSR case, the company allegedly committed an assault with a deadly weapon by the repeated exposure of employees to lead dust and the refusal by management to provide protective equipment to employees. Peter J. Howe, Firm Guilty in Lead Exposure, Boston Globe, Nov. 20, 1997, at B7.

[clxvii] In the European Union only two proceedings have been initiated (one in France and one in Belgium both against Total, a French corporation) but aborted very early. Wouters/Ryngaert supra note 132 , at 943 .

[clxviii] Fauchald/Stigen, supra note 43, at 1035.

[clxix] Francois Rigaux, An International (Criminal) Court for Transnational Companies?, article publié le 5/05/2001, Séminaire de travail: Les activités des sociétés transnationales et la nécessité de leur encadrement juridique Céligny, Genève, 4-5 mai 2001, Attac (Association pour la Taxation des Transactions pour l'Aide aux Citoyens), available at http://france.attac.org/spip.php?article2844 (last visited May 2010).

Possible criteria could be the country where the multinational corporation has requested legal identity, where it has its headquarters, or the place where the main decisions are taken.

[clxx] FAFO report supra note 47, at 22.

[clxxi] Ibid.

[clxxii] Wouters/Ryngaert supra note 132, at 945

[clxxiii] Ibid at 953.

[clxxiv] Stephens supra note 164, at 57.

[clxxv] Humphreys infra note 176, at 348.

[clxxvi] Steven L. Humphreys, An Enemy of The People: Prosecuting The Corporate Polluter As A Common Law Criminal (1990) 39 American University Law Review 311, at 318.

[clxxvii] Adler/Lord supra note 165, at 795.

[clxxviii] http://seattletimes.nwsource.com/html/nationworld/2012007007_oil02.html

[clxxix] However, this oil spill affects the United States directly. Years of oil spills in Nigeria by NNPC and Shell have not attracted this media attention or political reaction.

[clxxx] http://www.guardian.co.uk/world/2010/jun/01/trafigura-trial-toxic-waste-netherlands. See also Michael Peel, Lawyers Hunt for Big Game, The Financial Times, BUSINESS LIFE Jan. 31, 2008.

[clxxxi] Kyle Rex Jacobson, Doing Business with the Devil: The Challenges of prosecuting Corporate Officials Whose Business Transactions Facilitate War Crimes and Crimes Against Humanity (2005) 56 Air Force Law Review 167 at 218; S.C. Res. 1306, U.N. SCOR, 55th Sess., 4168th mtg. at 2, U.N. Doc. S/RES/1306 (2000).

[clxxxii] Ibid, at 218. 
[clxxxiii] For a more detailed debate on codes of conduct see Choudhury supra note 121, at 63ff.

[clxxxiv] OECD Working Party of the Trade Committee, Codes of Corporate Conduct: An Inventory (1999) available at http:// www.oecd.org/ech/index_2.htm (last visited May 2010), at 5.

[clxxxv] David Kinley and Junko Tadaki, From Talk To Walk: The Emergence Of Human Rights Responsibilities For Corporations At International Law, 44 Virginia Journal of International Law 931 (2004), at 953.

[clxxxvi] 246 Codes of conduct of which 118 were initiated by individual companies, 92 by industry and trade associations, 32 by partnerships between stakeholders and 4 by inter-governmental organizations. OECD, Working

Papers On International Investment, Number 2001/6, Codes of Corporate Conduct: Expanded Review of their Contents, May 2001 available at

http://www.oecd.org/dataoecd/57/24/1922656.pdf (last visited May 2010)

[clxxxvii] Kinley/Tadaki supra note 185, at 955.

[clxxxviii] John Christopher Anderson, (2000) University of Pennsylvania Journal of Labor and Employment Law 463, at 489.

[clxxxix] U.N. Conference on Trade and Development, The Social Responsibility of

Transnational Corporations, U.N. Doc. UNCTAD/ITE/IIT/Misc.21 (1999), available at

http://www.unctad.org/en/docs/poiteiitm21.en.pdf. (last visited May 2010), at 47.

[cxc] Kinley/Tadaki supra note 185, at 955 f.

[cxci] OECD study 2001, at 26.

[cxcii] Ibid.

[cxciii] Carbonnier, supra note 51, at 955.

[cxciv] Ibid., at 956

[cxcv] Ibid. at 955

[cxcvi] Alan E. Boyle, Saving the World? Implementation and Enforcement of International Environmental

Law Through International Institutions, (1991) 3 Journal of Environmental Law 229, at 230.

[cxcvii] Supra note 22.

[cxcviii] Need to ensure a healthy environment for the well-being of

individuals, UN GA Resolution A/RES/45/94, 68th plenary meeting, 14 December

1990 .

[cxcix] Jessup supra note 6, at 725 .

[cc] Developments in the Law-Corporate Liability for Violations of International Human Rights Law, supra note 114, at 2030-31.

[cci] Supra note 109.

[ccii] Ramasastry supra note 48 , at 96.

[cciii] Fisse speaks of "the quintessentially stigmatic corporate sanction" Brent Fisse, Reconstructing Corporate Criminal law: Deterrence, Retribution, Fault, and Sanctions, (1983) 56 South California Law Review 1141, at 1229

[cciv] Sean J. Bellew, Daniel T. Sturz, Criminal enforcement of Environmental Laws: A Corporate Guide to Avoiding Liability (1997) 8 Villanova Environmental Law Journal 205, 209.

[ccv] McLaughlin supra note 7, 390.

[ccvi] Bruch supra note 33, at 736.

[ccvii] See for example Audra E. Dehan, An International Environmental Court: Should There Be One?, 3 Touro Journal of Transnational Law 31, 52 (1992); Sean D. Murphy, Does the World Need a New International Environmental Court?, 32 Geo. Wash. J. Int'1 L. \& Econ. 333 (2000).

[ccviii] For example the need to agree on procedures, find a court seat with the relevant infrastructure and appoint staff.

[ccix] Bruch supra note 33, at 736.

[ccx] Article 22 Rome Statute

[ccxi] International Law Commission (ILC) Draft Articles on State Responsibility, U.N. GAOR, 51st

Sess., Supp. No. 10, art 19(3)(d), U.N. Doc. A/51/10 (1996).

[ccxii] Bruch supra note 33, at 720.

[ccxiii] Berat supra note 29, at 340.

[ccxiv] McLaughlin, supra note 7, at 396.

[ccxv] A similar approach was taken when drafting Article 8, which encompasses only those violations of 
international humanitarian law on which the member states could agree.

[ccxvi] Article 30 I Rome Statute

[ccxvii] Article 28 (2) (a).

[ccxviii] Additional Protocol I Article 35(3)

[ccxix] BBC news Tuesday, 23 September, 2003 available at: http://news.bbc.co.uk/1/hi/business/3133108.stm

[ccxx] For an overview of prosecutions against corporate officials before post-world war II tribunals see Jacobson supra note 181, 177-199.

[ccxxi] See George Wald, Corporate Responsibility for War Crimes, 15 New York Review of Books July 2,

1970, at 4. Wald suggests that Dow Chemical Corporation should be prosecuted for supplying napalm to United States forces in the Vietnam conflict. For a discussion of the prosecution of Corporate Officials after world War II see Jacobson, supra note 181, 167.

[ccxxii] Brent Fisse and John Braithwaite, The Allocation of Responsibility for Corporate Crime: Individualism, Collectivism and Accountability, 11 Sydney Law Review 468.

[ccxxiii] Fauchald/Stigen, supra note 43, at 1043.

[ccxxiv] See Regina Rauxloh, A Call For the End of Impunity for Multinational Corporations', (2008) 14 Texas

Wesleyan Law Review 297.

[ccxxv] Kinley/Tadaki supra note 185, at 961.

[ccxxvi] Stephens supra note 164, at 46.

[ccxxvii] John R. Billington, Recent New Zealand Efforts to Combat Environmental Crime (1995)

6 Criminal Law Forum 389, at 402.

[ccxxviii] United States Department of Justice, Factors in Decisions on Criminal Prosecutions for Environmental Violations in the Context of Significant Voluntary Compliance or Disclosure Efforts by the Violator available at http://www.justice.gov/enrd/Factors_in_decisions.html (last visited May 2010).

[ccxxix] For example the post-election violence in Kenya ICC-01/09 Public Court Records - Pre-Trial Chamber II Decision Pursuant to Article 15 of the Rome Statute on the Authorization of an Investigation into the Situation in the Republic of Kenya (March 31, 2010).

[ccxxx] Stockholm Declaration supra note 32, at 6.

[ccxxxi] Berat supra note 29, at 340 . 